\title{
Centra dystrybucji i sortownie przyszłości - przykład zastosowania robotyki w logistyce
}

http://dx.doi.org/10.18778/8142-085-3.12

\author{
Joanna Litewska \\ Katedra Logistyki Międzynarodowej \\ Uniwersytet Ekonomiczny w Poznaniu
}

\section{Wstęp}

Obecnie dostrzec można wiele trendów technologicznych, które w ciągu następnych kilku lat pozytywnie wpłyną na działalność wielu przedsiębiorstw, nie tylko tych z branży TSL. Wśród wiodących znajdują się wytwarzanie energii odnawialnej, drukarki 3D, analityka Big Data, autonomiczne pojazdy czy eHealth ${ }^{1}$. Znaczący pozytywny wpływ na społeczeństwo będzie miał również rozwój zaawansowanych robotów. Słownik Języka Polskiego PWN definiuje robota jako „urządzenie zastępujące człowieka przy wykonywaniu niektórych czynności”2. Jest to dobra definicja, jednak wydaje się nie obejmować autonomicznych samochodów, dronów czy przenośników taśmowych. Można by ją zatem rozszerzyć o wiele innych elementów. Na potrzeby niniejszego opracowania autorka przyjęła nieco inną definicję robota, w większym stopniu odnoszącą się do jego zastosowań w logistyce. Zatem „robot to wynalazek wykorzystywany do usprawniania i automatyzacji procesów logistycznych zachodzących w magazynach, sortowniach i centrach dystrybucji. Może być stacjonarny lub mobilny, a także posiadać chwytaki do podnoszenia i zmiany lokalizacji przedmiotów".

Zgodnie z pierwszą definicją, można stwierdzić, że innowacyjne roboty towarzyszą nam każdego dnia. Wspierają lekarzy podczas operacji, pielęgniarki w dostarczaniu pacjentom posiłków i lekarstw na czas, a także współpracują z pracownikami fabryk przy montażu i produkcji. W naszym codziennym życiu towarzyszą nam również roboty osobiste, np. takie koszące trawnik, podlewające ogród czy

1 Nowoczesna praktyka w branży zdrowotnej, polegająca na wsparciu tradycyjnych procesów narzędziami informatycznymi, w tym wirtualnymi (bazy danych, serwery, witryny).

2 Słownik Języka Polskiego PWN, http://sjp.pwn.pl/slowniki/robot.html [dostęp 20.04.2017]. 
odkurzające mieszkanie. Istnieją także roboty-protezy, które pozwalają pacjentom z amputowanymi kończynami aktywnie uczestniczyć w życiu społecznym.

Wszystkie wyżej wspomniane roboty podnoszą jakość codziennego życia ludzi, wykonując niebezpieczne, ryzykowne i nużące czynności z niesamowitą precyzją i dokładnością. Nie są to jednak roboty, których definicja pokrywa się z tą drugą, przytoczoną w kontekście logistyki - wymienione wyżej zastosowania robotów raczej nie dotyczą branży TSL. W ostatnich kilku latach natomiast firmy zajmujące się tworzeniem rozwiązań z zakresu robotyki coraz częściej dostrzegają potencjał ich wykorzystania w logistyce. Nieunikniony rozwój w tym zakresie przyniesie korzyści nie tylko pracownikom, ale również klientom, którzy dostrzegą poprawę w szybkości dostawy i wyższą jakość świadczonych im usług.

W poniższym opracowaniu ukazane zostały dostępne na rynku rozwiązania z zakresu robotyki dla logistyki. Autorka przedstawiła również przyszłościową wizję w pełni zautomatyzowanych centrów dystrybucji i sortowni, które do swojego funkcjonowania wykorzystywać będą roboty wielu różnych typów. Zaprezentowane rozwiązania mogą stanowić inspirację dla wielu różnych firm, nie tylko tych z branży logistycznej.

\section{Bariery i przestanki rozwoju robotyki}

Pierwszy robot przemysłowy, o nazwie Unimate, stworzony został w roku 1961 w fabryce samochodów General Motors ${ }^{3}$. Jego zadaniem było chwytanie i przenoszenie określonego rodzaju części z jednego miejsca na drugie. Podobnie większość robotów powstających między latami 60 . XX wieku a czasami współczesnymi przeznaczona była do pracy na produkcji, głównie w branży automotive. Tylko nieliczne rozwiązania stworzone zostały z myślą o wsparciu logistyki czy dystrybucji, czego główną przyczyną była bariera technologiczna. Roboty występowały tylko w wersji stacjonarnej i programowane były do wykonywania określonego, wąskiego zakresu ruchów i czynności. W logistyce, gdzie głównym polem wykorzystania robotów byłoby prawdopodobnie automatyczne kompletowanie zamówień, stosowane do tej pory systemy i technologie nie miałyby większego zastosowania. Potwierdziły to liczne nieudane próby wdrożenia zaawansowanych robotów w tej branży. Ponadto jeszcze do niedawna roboty nie potrafiły odróżniać ludzi od towarów, a zatem zagrażały bezpieczeństwu znajdujących się w ich otoczeniu osób. Uniemożliwiało to wykorzystanie ich w centrach dystrybucji, magazynach i sortowniach.

3 Retronauta.pl, Unimate - pierwszy robot przemysłowy (1961), 2015, http://www.retronauta.pl/ unimate-pierwszy-robot-przemyslowy [dostęp 21.04.2017]. 
Oprócz wyzwań technologicznych, na wolniejszy niż się spodziewano rozwój robotyki wpłynął także brak dostatecznego finansowania. Dziś fundusze na te cele pochodzą z trzech źródeł: dotacji rządowych, funduszy venture capital oraz od czołowych graczy rynkowych, takich jak Google czy Amazon. W roku 2012 rząd USA wsparł w ten sposób ponad 30 grup naukowców pracujących nad rozwojem robotyki w kraju. Był to pierwszy element, wspieranego przez ówczesnego prezydenta Barracka Obamę, programu National Robotics Initiative (NRI), którego celem było stworzenie następnej generacji robotów dla gospodarki ${ }^{4}$.

Znaczącą barierę rozwoju robotyki stanowiły również wysoki koszt sensorów oraz niewystarczające moce obliczeniowe do przetwarzania ogromnych ilości danych i korzystania z zaawansowanych algorytmów w czasie rzeczywistym. Ostatnie osiągnięcia nauki i techniki wskazują jednak na nadchodzącą zmianę w tym zakresie. Innowacyjne technologie sprawią, że już niedługo roboty będą posiadały zdolność identyfikowania obiektów, lokalizowania ich pozycji, planowania ścieżki, jaką muszą pokonać w celu pozyskania danego produktu, a także umieszczania go w docelowej lokalizacji. Podczas projektowania następnej generacji robotów dla logistyki najważniejszym elementem będzie jednak „mózg”, który pozwoli na koordynację wszystkich wyżej wymienionych czynności, zaawansowaną percepcję, mobilność i umiejętność współpracy z ludźmi. Potrzebna będzie do tego potężna moc i prędkość obliczeniowa. Projektanci robotów starają się zatem maksymalnie wykorzystywać dostępne technologie. Przykładowo, chipy komputerowe z gier wideo (GPUs - Graphic Processing Units), stworzone do szybkich obliczeń i wyświetlania skomplikowanych, zmieniających się często grafik, używane są obecnie do przetwarzania obrazów z kamer zainstalowanych w robotach ${ }^{5}$. Aby jednak odtworzyć ludzki mózg, takich chipów potrzeba więcej niż 500000 - montowanie ich w każdym robocie znacząco podwyższyłoby koszty produkcji. Większość robotów wykorzystywanych w przyszłości w logistyce nie będzie jednak potrzebowała aż tak wielkich mocy obliczeniowych. Rozwiązaniem może być tzw. cloud robotics - koncepcja, według której wiele nieskomplikowanych technologicznie robotów mogłoby korzystać jednocześnie z jednego komputera, sterującego ich działaniami ${ }^{6}$.

Koncepcję „robotów w chmurze” przetestował w 2013 roku, we współpracy z Google, zespół badaczy z Uniwersytetu w Kalifornii . Robot, przy wykorzystaniu kamery, robił zdjęcia umieszczonych przed nim elementów i przesyłał je do serwerów Google. Superkomputery, korzystając z metod analizy Big Data, identyfikowały obiekt

4 National Robotics Initiative, The realization of co-robots acting in direct support of individuals and groups, https://www.nsf.gov/pubs/2012/nsf12607/nsf12607.htm [dostęp 21.04.2017].

5 DHL, Robotics in Logistics - a DPDHL perspective on implications and use cases for the logistics industry, March 2016.

6 RoboEarth - What is cloud robotics?, http://roboearth.ethz.ch/cloud_robotics/ [dostęp 16.04.2017).

7 Tamże. 
i odsyłały informację zwrotną o tym, jak najlepiej do niego dotrzeć i jak go podnieść. Najlepszym przykładem działającego na zasadzie chmury robota, który obecnie dostępny jest w sprzedaży, jest humanoid o nazwie Pepper. ${ }^{8}$ Posiada on cechy zbliżone do ludzkich - potrafi komunikować się używając mowy i dotyku, jak również rozpoznawać i okazywać emocje. Wszystkimi tymi skomplikowanymi ruchami i reakcjami steruje komputer w Japonii, do którego robot podłączony jest za pomocą Internetu. Rodzi to pewne obawy o bezpieczeństwo przesyłanych danych, jednak problem ten jest już powszechnie znany i nad rozwiązaniem go pracuje obecnie wiele firm.

Jednym z największych wyzwań, jakie stoją obecnie przed branżą logistyczną, jest niska dostępność siły roboczej, co w połączeniu z rosnącą wagą i liczbą przesyłek oraz średnią odległością przewozu stwarza konieczność poszukiwania alternatywnych rozwiązań. W dobie e-commerce problem ten będzie narastał. Firmy przestają już operować wielkościami hurtowymi - zamiast tego muszą każde drobne zamówienie złożone drogą elektroniczną pobrać z magazynu i zapakować ręcznie. Zwiększone zapotrzebowanie na siłę roboczą pojawia się również podczas dalszej obsługi zamówień, które często muszą być dostarczane jako oddzielne przesyłki, bezpośrednio do rąk klientów. Aby sprostać tym wyzwaniom, menedżerowie przyszłych łańcuchów dostaw będą musieli albo podnosić koszy i redukować zakres działalności (co nie jest zgodne z głównym celem funkcjonowania przedsiębiorstw), albo kompensować brak siły roboczej automatyzacją. Obecne rozwiązania automatyki nie są jednak wystarczająco elastyczne, aby sprostać wymaganiom dynamicznie zmieniającego się charakteru łańcuchów dostaw, powstaję więc pole do rozwoju inteligentnych, łatwo skalowalnych rozwiązań z zakresu robotyki.

\section{Zastosowanie robotyki w logistyce}

Dorobek techniki ostatnich lat, o którym autorka wspomniała w poprzednim rozdziale, stworzył nowe możliwości wykorzystania robotyki w procesach logistycznych. Przesłanki automatyzacji wynikające z malejącej dostępności siły roboczej wydają się potwierdzać ten kierunek rozwoju. Jest to jednak wizja przyszłościowa - zdecydowana większość współczesnych magazynów działa bez wsparcia zarówno automatyki, jak i robotyki ${ }^{9}$ - czynności wykonywane są ręcznie, przez

8 Soft Bank Robotics, Pepper, https://www.ald.softbankrobotics.com/en/cool-robots/pepper [dostęp 16.04.2017].

9 Logistyka.net.pl, Roboty wspótpracujące z ludźmi przekształca branżę usług logistycznych, http://www.logistyka.net.pl/aktualnosci/logistyka/item/87206-roboty-wspolpracujace-zludzmi-przeksztalca-branze-uslug-logistycznych [dostęp 17.04.2017]. 
zatrudnionych magazynierów, którzy liczyć mogą jedynie na wsparcie prostego w obsłudze przenośnego terminala.

Częściowo zmechanizowane jest natomiast 15\% magazynów ${ }^{10}$. Korzystają one z takich rozwiązań jak przenośniki, sortery czy systemy do automatycznego pobierania towaru, które pozwalają na poprawę wydajności i produktywności pracy personelu.

Całkowicie zautomatyzowane jest obecnie ok. 5\% magazynów ${ }^{11}$, które należą do wiodących firm na rynku, takich jak Amazon. Przedsiębiorstwa te, pomimo posiadanej technologii, wciąż jednak zatrudniają w sortowniach i centrach dystrybucji mnóstwo ludzi. Ich praca polega głównie na załadunku i wyładunku samochodów, kontenerów czy obsłudze niewymiarowych ładunków. Dlaczego takich czynności nie powierzyć robotom?

\subsection{Roboty do rozładunku naczep i kontenerów}

Znaczna część dóbr sprzedawanych w Europie i USA pochodzi z Azji, skąd transportowana jest luzem (bez użycia palet) w standaryzowanych kontenerach. Skutkuje to brakiem możliwości wykorzystania do rozładunku jakichkolwiek wózków widłowych. Aby możliwe było magazynowanie takiego towaru, konieczna jest późniejsza paletyzacja. Podobnie dzieje się z transportami dalekiego zasięgu z użyciem aut, które ładowane bez użycia palet, stwarzają konieczność zatrudnienia dodatkowej siły roboczej do rozładunku. W 2003 roku DHL, wraz z partnerami biznesowymi, stworzył prototyp robota do rozładunku o nazwie „The Parcel Robot”. Zbudowano go z podwozia, teleskopowego przenośnika taśmowego, skanera laserowego 3D oraz systemu do chwytania, na który składało się przegubowe ramię oraz chwytak ${ }^{12}$. Robot, umieszczany na wprost kontenera, skanował wszystkie elementy do rozładowania, używając skanera laserowego 3D. Zintegrowany z robotem komputer analizował następnie kształt i wielkość przesyłek, na podstawie których opracowywał optymalną kolejność rozładunku. Robot pobierał elementy w podanej kolejności i umieszczał je na przenośniku, skąd trafiały w głąb magazynu, wprost na paletyzację. Technologia była bardzo obiecująca, jednak wskutek niedopracowania nie weszła na rynek w 2003 roku. W ciągu następnych lat powstawać zaczęły jednak rozwinięcia pierwotnej koncepcji DHL. Obecnie flagowymi rozwiązaniami są te produkowane przez firmę Wynright, która opracowała robota rozładowu-

10 DHL, Robotics in Logistics - a DPDHL perspective on implications and use cases for the logistics industry, March 2016.

11 Tamże.

12 Deutsche Post DHL Group, Parcel Robot, http://www.dpdhl.com/en/media_relations/ media_library/videos/parcel_robot.html [dostęp 17.04.2017]. 
jącego nadwozia i kontenery z prędkością 500 kartonów na godzinę ${ }^{13}$. Używa do tego celu kamery - mniej kosztownego rozwiązania niż skanery laserowe 3D zaproponowane przez DHL. Obecnie firmy pracują także nad robotami, które zapewniałyby nie tylko rozładunek, ale i optymalny załadunek jednostek ładunkowych.

\subsection{Stacjonarne roboty do pobierania jednostek towaru}

Tradycyjny pracownik magazynowy spędza przeważnie większość czasu na przemieszczaniu się po magazynie w celu zebrania wszystkich elementów zamówienia. By zaoszczędzić ten czas i zasoby, firma Kiva zdecydowała się na rozwój robotów, które przynoszą do pracownika stojącego w miejscu element regału, na którym znajduje się poszukiwany towar ${ }^{14}$. Kiedy pracownik pobierze odpowiedni towar, półka wraca na swoje miejsce. Wykształcona w ten sposób koncepcja nosi nazwę goods to picker. Jest to jednak rozwiązanie kapitałochłonne i nie eliminuje całkowicie personelu magazynowego. Dostrzegając ten problem, firmy zaczęły wyposażać roboty w ramiona. $\mathrm{W}$ ten sposób powstały roboty stacjonarne, które używają kamer do identyfikowania przedmiotów na podjeżdżających do nich półkach, a następnie chwytają wybrany przedmiot i umieszczają go na przenośniku taśmowym. Przykładowy robot SSI Schaefer może pobrać nawet 2400 jednostek towaru w godzinę ${ }^{15}$. Nieco bardziej zaawansowany, taki jak Knapp, może również dostosowywać chwytak do wielkości i kształtu produktu $^{16}$, a Viastore ma możliwość poza tym umieszczać pobrane produkty w finalnym opakowaniu transportowym (Pick'n'Pack) ${ }^{17}$.

Podstawowym problemem w kontekście tego typu rozwiązań jest jednak kosztowny system i unikalna, personalizowana technologia przemieszczania półek. Stacjonarne roboty do pobierania towaru mogą być zatem istotną automatyzacją z punktu widzenia największych magazynów, jednak średnie i małe firmy nie będą w stanie sobie na nie pozwolić.

13 DHL, Robotics in Logistics - a DPDHL perspective on implications and use cases for the logistics industry, March 2016.

14 Business Insider, Wmagazynach Amazona pracuje coraz więcej robotów, http://businessinsider. com.pl/technologie/w-magazynach-amazona-pracuje-coraz-wiecej-robotow/h9bgt5j [dostęp18.04.2017].

15 SSi Schaefer, Order Picking Robot: SSI Robo-Pick, http://www.ssi-schaefer.de/en/conveyingand-picking/automatic-order-picking/order-picking-robot.html [dostęp 15.04.2017].

16 Knapp Robotics, https://www.knapp.com/loesungen/technologien/lagern/ [dostęp 16.04.2017].

17 Viastore, http://www.us.viastore.com/warehouse-systems/robotics/ [dostęp 16.04.2017]. 


\subsection{Mobilne roboty do pobierania jednostek towaru}

Rozwiązaniem przeciwnym do opisanego powyżej picker to goods jest mobilny robot, który porusza się między regałami w magazynie i pobiera towar jak standardowy pracownik. Takie rozwiązania ma już w swojej ofercie kilka start-upów ${ }^{18}$ :

- IAM Robotics - mała firma z USA. Opracowała robota, który posiada ramię do chwytania, skaner 3D oraz system kamer, które umożliwiają nawigację po magazynie ${ }^{19}$. System przetestowany został $\mathrm{w}$ magazynie $\mathrm{z}$ farmaceutykami w Nowym Jorku. Robot potwierdził swoją skuteczność, pobierając 40 jednostek towaru, którego nigdy wcześniej nie widział ${ }^{20}$. System wyposażony jest dodatkowo $\mathrm{w}$ oprogramowanie, które łatwo integruje się $\mathrm{z}$ wewnętrznym systemem WMS. Pozwala na nadzór nad robotem, przekazywanie mu zleceń, jak również generowanie wskaźników produktywności.

- Fetch Robotics - to start-up, który stworzył cały system współdziałania robotów. Robot (Fetch) współpracuje z drugim, mniejszym (Freight), który podąża za nim z pojemnikiem na elementy zamówienia ${ }^{21}$. Każdy Fetch może mieć kilka robotów Freight, odpowiedzialnych za dostarczanie gotowych, skompletowanych zamówień do strefy wydań. Fetch odpowiedzialny jest tylko za przydzielanie odpowiednich produktów do odpowiednich pojemników. Stanowi to zatem hybrydę dwóch koncepcji: towar do pracownika i tej tradycyjnej - pracownik do towaru. Producent postanowił też sprzedawać oddzielnie roboty Freight, które pomagałyby pracownikom w magazynach o niestandardowych wymiarach na wykorzystanie robota Fetch.

- Magazino - to niemiecki start-up, który opracowuje i rozwija mobilne roboty dla gospodarki magazynowej. Jego ostatnim wynalazkiem jest robot TORU, stworzony do pickingu towarów. Składa się z kilku poziomów komór na pobrane towary, systemu chwytania oraz kamer 2D i 3D, dzięki którym potrafi identyfikować pojedyncze obiekty na półce ${ }^{22}$. TORU przystosowany jest do pracy wśród ludzi, zapewniając dostawę skompletowanego zamówienia do strefy wydań dokładnie na czas. Firma pracuje również nad nowym rozwiązaniem SOTO, którego premiera ma odbyć się jeszcze w 2017 roku $^{23}$. Zadaniem SOTO będzie zapewnianie ciągłości działania magazynów i hal produkcyjnych poprzez uzupełnianie na bieżąco pojemników potrzebnych do pickingu czy dostarczanie odpowiednich elementów do produkcji.

18 DPDHL, Robotics in Logistics - a DPDHL perspective on implications and use cases for the logistics industry, March 2016.

19 I am robotics. Solutions, https://www.iamrobotics.com/solutions [dostęp 15.04.2017].

20 DPDHL, Robotics in Logistics - a DPDHL perspective on implications and use cases for the logistics industry, March 2016.

21 Fetch robotics, http://fetchrobotics.com/ [dostęp 17.04.2017].

22 MAGAZINO simple storage, https://www.magazino.eu/toru/?lang=en [dostęp 18.04.2017].

23 Tamże. 


\subsection{Roboty do przepakowywania i etykietowania}

Obecnie każdy bardziej znaczący na rynku producent drobnych artykułów spożywczych i codziennego użytku musi liczyć się z koniecznością dostosowywania swoich produktów do potrzeb klientów. Codziennością jest otrzymywanie od supermarketów żądań dotyczących na przykład stworzenia zestawów promocyjnych czy umieszczenia na opakowaniu naklejki informującej o promocji. Są to czynności proste, polegające zwykle na otwarciu opakowania, umieszczeniu kilku naklejek i zamknięciu go z powrotem. Wymagają jednak czasu oraz generują koszty.

Firma Rethink Robotics stworzyła robota o nazwie Baxter, który z powodzeniem pracuje w otoczeniu ludzi. Posiada dwa ramiona, które wyłączają się, gdy robot w coś uderzy, jak również sensory, które hamują robota w przypadku pojawienia się ludzi $\mathrm{w}$ jego otoczeniu ${ }^{24}$. Baxter może identyfikować i pobierać odpowiednie towary dzięki trzem wbudowanym kamerom. Jego podstawową zaletą jest możliwość nauczenia go wykonywania pewnych czynności poprzez złapanie jednego $\mathrm{z}$ ramion i wykonanie nim określonych ruchów. Robot szybko nauczy się prostych zadań i będzie mógł wykonywać je sam. Powinien zatem idealnie sprawdzić się do czynności typu umieszczanie naklejek na produktach. Robot nie przeszedł jednak większości testów w warunkach laboratoryjnych. Firma opracowała zatem nowe rozwiązanie - robota Sawyer. Technologia nie jest jeszcze w pełni gotowa, jednak wydaje się, że rozwiąże wszelkie problemy, jakie pojawiły się podczas testowania Baxtera ${ }^{25}$.

\subsection{Domowe roboty dostawcze}

W 2016 roku firma Starship Technologies stworzyła prototyp autonomicznego robota dostawczego, który porusza się po chodnikach z prędkością $6 \mathrm{~km} / \mathrm{h}$ i może dostarczać produkty klientom bezpośrednio do ich domów znajdujących się w promieniu $5 \mathrm{~km}^{26}$. Robot przystosowany jest do przewożenia mniej więcej dwóch toreb zakupów i dostarczenia ich do klienta bezpośrednio z centrum dystrybucji lub supermarketu w przeciągu $30 \mathrm{~min}$.

Oprócz szybkiego czasu dostawy klienci skorzystają na rozwiązaniu również w inny sposób. Będą mogli bowiem wybierać dokładnie, o której godzinie i gdzie podjechać ma ich automatyczny „,dostawca”, a także śledzić jego położenie w czasie rzeczywistym dzięki mobilnej aplikacji. Zastrzeżeń nie budzą również kwestie bezpieczeństwa - robota będzie mógł otworzyć tylko klient przy pomocy swojego smartfona.

24 Rethink Robotics, Baxter, http://www.rethinkrobotics.com/baxter/ [dostęp 17.04.2017].

25 Rethink Robotics, Sawyer, http://www.rethinkrobotics.com/sawyer/ [dostęp 19.04.2017].

26 Starship Technologies, https://www.starship.xyz/ [dostęp 18.04.2017]. 
Ponadto, ze względu na osiąganą prędkość wynoszącą maksymalnie zaledwie $6 \mathrm{~km} / \mathrm{h}$ oraz wbudowane kamery umożliwiające omijanie przeszkód, robot nie stanowi zagrożenia dla ludzi czy mienia. Dodatkowo, ze względu na minimalną emisję zanieczyszczeń, może z powodzeniem stać się alternatywą dla ekologicznych dronów.

\section{6. „,Roboty - kurierzy”}

Konieczność redukowania emisji zanieczyszczeń i kosztów ponoszonych na masowy transport stwarza pole dla rozwoju drobnych, ekologicznych form transportu. Znane od dawna i wspomniane wcześniej drony to tylko jedno z rozwiązań. Drobne przesyłki będą mogły być także odbierane z sortowni przez małe mobilne roboty. Podobnie jak w przypadku domowych robotów dostawczych, będzie można śledzić je za pomocą aplikacji. Robot w momencie podjeżdżania do budynku będzie wykonywać połączenie do odbiorcy, informując go o nadchodzącej dostawie i przesyłając indywidualny kod odbioru.

Duże przesyłki natomiast nadal dostarczane będą przez kurierów, jednak ze wsparciem robotów zwanych exoskeletons, przystosowanych do przenoszenia ciężkich ładunków.

\section{Logistyka przysztości oparta na robotyce}

W poprzednich rozdziałach ukazane zostały pomysły, prototypy rozwiązań oraz dostępne na rynku wynalazki z dziedziny robotyki. Co stanie się, kiedy wszystkie znajdą się już w masowej sprzedaży? Jak zmieni się świat logistyki napędzanej rozwojem robotyki? W tej części opracowania autorka ukazała dwie utopijne koncepcje przyszłości - centra dystrybucji oraz sortownie - oparte na badaniach przeprowadzonych przez firmę DHL ${ }^{27}$. Obydwa ogniwa łańcucha dostaw będą w pełni zautomatyzowane i oparte na dostępnych w przyszłości rozwiązaniach z dziedziny robotyki.

\subsection{Centrum dystrybucji}

Roboty pozwolą na usprawnienie centrów dystrybucji niemal w każdym aspekcie. Obiekty te będą bardziej elastycznie reagować na zmiany, a co za tym idzie, będą przyczyniały się do wzrostu produktywności całego łańcucha.

27 DHL, Robotics in Logistics - a DPDHL perspective on implications and use cases for the logistics industry, March 2016. 
Nowe operacje pozwolą na zaangażowanie różnych typów robotów, przystosowanych do wykonywania określonego zakresu prac. Większość z nich będzie mobilna i autonomiczna, koordynowana przez zaawansowane systemy typu WMS, które pozwolą na śledzenie pracy robotów, przydzielanie zadań i kontrolę nad jakością wykonywanych przez nie obowiązków. W centrum dystrybucji występować będą następujące rozwiązania robotyki:

- mobilne roboty do pickingu,

- systemy goods-to-picker,

- roboty typu exoskeleton wspomagające ludzi,

- mobilne roboty nadzorujące operacje magazynowe,

- zautomatyzowane zarządzanie magazynem z wykorzystaniem dronów,

- autonomiczny transport wykorzystujący exoskeletony i mobilne roboty dostawcze.

W takim centrum dystrybucji zmniejszy się liczba wąskich gardeł i punktów zapalnych. Każdy robot bowiem, jako indywidualnie działająca jednostka, będzie mógł być w przypadku awarii szybko eliminowany z procesu i zastąpiony modelem zapasowym na czas naprawy. Zapasowe roboty będą wyjściowo podłączone do chmury, co spowoduje automatyczne pobranie całego potrzebnego do wykonania pracy know how.

Obecna rola personelu magazynowego pójdzie zatem w niepamięć. Osoby pracujące w magazynie odpowiedzialne staną się jedynie za czynności wyższego szczebla, takie jak zarządzanie operacjami, koordynowanie przepływów, naprawianie robotów czy indywidualną obsługę trudnych, niestandardowych zamówień i wyjątków. Będą także odpowiadać za elastyczność i skalę działalności operacyjnej, dostosowując moce przerobowe do zmieniającego się popytu. W razie potrzeby ludzie dostarczą towary do strefy pakowania, gdzie mobilne roboty będą przekształcały standardowe produkty w zestawy promocyjne, zgodne $\mathrm{z}$ indywidualnymi zamówieniami klientów.

Zjawiskiem, które również będziemy obserwować w przyszłości, jest leasing i wynajem robotów, który pozwoli przedsiębiorstwom na zmniejszenie kosztów, obniżenie poziomu aktywów trwałych i zwiększenie operacyjnej elastyczności.

\subsection{Sortownia przyszłości}

W przeciwieństwie do dzisiejszych sortowni, te w przyszłości będą pracować 24/7 (aby stworzyć spójny mechanizm z centrami dystrybucji, również pracującymi w trybie ciągłym). Co więcej, ostatnia zmiana będzie tak samo efektywna jak pierwsza.

Praca sortowni odbywać się będzie w trybie „falowym” - przesyłki wydawane będą do dostarczenia kilka razy dziennie. Zapewni to szybszą dostawę do klienta oraz pozwoli na obniżenie kosztów. W sortowniach zastosowane zostaną następujące rozwiązania: 
- rozładunek i załadunek autonomicznych pojazdów wykonywany przez roboty,

- „mobilne przenośniki taśmowe” dobierane indywidualnie do każdej przesyłki,

- automatyczne, sterowane z centralnego komputera sortowanie, odbywające się podczas przejazdu przenośników od strefy rozładunku do strefy załadunku,

- uzupełnianie paczkomatów przez roboty,

- autonomiczna flota dostawcza: mobilne roboty i drony.

Towary dostarczane będą do sortowni autonomicznymi pojazdami, zgodnie z opracowanymi komputerowo slotami rozładunkowymi. Następnie roboty posiadające ramiona będą rozładowywać pojazd i umieszczać poszczególne przesyłki na indywidualnych przenośnikach - sorterach. Takimi przenośnikami będą drobne, mobilne roboty, zdolne do przenoszenia po jednej przesyłce $\mathrm{z}$ rampy rozładunkowej do odpowiednich punktów załadunku. Sortowanie będzie odbywać się zdalnie - podczas przemieszczania się przenośników przez sortownię, komputer centralny przydzieli im rampę załadunkową oraz przekaże informacje o kolejności załadunku. Przenośniki będą ustawiały się tak, aby umożliwić późniejszy, zgodny z trasą, wyładunek przesyłek. Większość dostarczonych przez mobilne przenośniki przesyłek obsługiwana będzie przez ramiona robotów i umieszczana w autonomicznych pojazdach. Część drobnych przesyłek natomiast zostanie załadowana na drony, które będą mogły dotrzeć nawet do nieosiągalnych dla aut destynacji. Przesyłki przeznaczone bezpośrednio do klientów indywidualnych, którzy znajdują się w otoczeniu sortowni (w odległości $5 \mathrm{~km}$ ), ładowane będą na mobilne roboty do transportu przesyłek. Wszystkie te czynności nadzorowane będą przez pracowników, odpowiadających także za przepływ pracy czy procesowanie niestandardowych przesyłek.

Korzyści płynących z wykorzystania rozwiązań robotyki w sortowniach jest wiele. To przede wszystkim zwiększona prędkość obsługi przesyłek, elastyczność, wyższa produktywność, a co za tym idzie - wyższa jakość świadczonych klientom usług.

\section{Podsumowanie}

Przewiduje się, że sektor logistyczny będzie w nadchodzących latach cierpiał z powodu braku wykwalifikowanej siły roboczej. Jest to pole do wprowadzenia robotów, które wesprą pracowników w codziennych obowiązkach i zmniejszą zapotrzebowanie na ludzi do pracy. Pozwolą na to zmniejszające się bariery techno- 
logiczne czy finansowe. Stosunkowo tanie sensory i szybkie komputery sprawiają dodatkowo, że pomysły wcześniej niemożliwe do zrealizowania staną się osiągalne. Prym w dziedzinie robotyki wiedzie Amazon, który inwestuje potężny kapitał w rozwój robotyki każdego roku ${ }^{28}$.

Przed robotyką jest jeszcze długa droga, zanim rozwiązania staną się dostępne dla większości przedsiębiorstw, jednak widać znaczący trend w ich rozwoju i zmniejszanie się kosztów produkcji robotów. Roboty staną się ponadto bardziej widoczne i zaczną bezpośrednio oddziaływać na nasze domy, ulubione sklepy czy biura, w których pracujemy. Styczność społeczeństwa z robotami będzie zatem czymś codziennym. Ludzie nie będą się bali przemieszczać po chodniku razem $\mathrm{z}$ robotami czy powierzać im swoich zakupów do dostarczenia. Wykorzystując cloud computing, będzie można także zarządzać wieloma robotami pracującymi w jednym centrum dystrybucji czy w sortowni. Liderzy muszą zrozumieć tę technologię i zacząć planować przyszłość firm opartą na rozwiązaniach robotyki, bowiem postęp w tworzeniu coraz to nowych rozwiązań widoczny jest niemal codziennie. Kwestią nie jest zatem, czy roboty będą w przyszłości wspierać logistykę, ale raczej, kiedy to nastąpi i na jaką skalę.

\section{Bibliografia}

Bloomberg, How Amazon Triggered a robot arms race, https://www.bloomberg.com/news/articles/2016-06-29/how-amazon-triggered-a-robot-arms-race [dostęp 20.04.2017].

Business Insider, W magazynach Amazona pracuje coraz więcej robotów, http://businessinsider. com.pl/technologie/w-magazynach-amazona-pracuje-coraz-wiecej-robotow/h9bgt5j [dostęp 18.04.2017].

Deutsche Post DHL Group, Parcel Robot, http://www.dpdhl.com/en/media_relations/media_library/videos/parcel_robot.html [dostęp 17.04.2017].

DHL, Robotics in Logistics - a DPDHL perspective on implications and use cases for the logistics industry, March 2016.

Fetch robotics, http://fetchrobotics.com/ [dostęp 17.04.2017].

I am robotics. Solutions, https://www.iamrobotics.com/solutions [dostęp 15.04.2017].

Knapp Robotics, https://www.knapp.com/loesungen/technologien/lagern/ [dostęp 16.04.2017]. Logistyka.net.pl, Roboty wspótpracujące z ludźmi przekształcą branżę usług logistycznych, http:// www.logistyka.net.pl/aktualnosci/logistyka/item/87206-roboty-wspolpracujace-z-ludzmiprzeksztalca-branze-uslug-logistycznych [dostęp 17.04.2017].

MAGAZINO simple storage, https://www.magazino.eu/toru/?lang=en [dostęp 18.04.2017].

28 Bloomberg, How Amazon Triggered a robot arms race, https://www.bloomberg.com/news/ articles/2016-06-29/how-amazon-triggered-a-robot-arms-race [dostęp 20.04.2017]. 
National Robotics Initiative - The realization of co-robots acting in direct support of individuals and groups, https://www.nsf.gov/pubs/2012/nsf12607/nsf12607.htm [dostęp 21.04.2017]. Rethink Robotics, Baxter, Sawyer, http://www.rethinkrobotics.com/baxter/ [dostęp 17.04.2017], http://www.rethinkrobotics.com/sawyer/ [dostęp 19.04.2017].

Retronauta.pl, Unitude - pierwszy robot przemysłowy (1961), http://www.retronauta.pl/unimate-pierwszy-robot-przemyslowy [dostęp 21.04.2017].

RoboEarth - What is cloud robotics?, http://roboearth.ethz.ch/cloud_robotics/ [dostęp 16.04.2017].

Słownik Języka Polskiego PWN, http://sjp.pwn.pl/slowniki/robot.html [dostęp: 20.04.2017].

Soft Bank Robotics. Pepper, https://www.ald.softbankrobotics.com/en/cool-robots/pepper [dostęp 16.04.2017].

SSi Schaefer, Order Picking Robot, SSI Robo-Pick, http://www.ssi-schaefer.de/en/conveying-andpicking/automatic-order-picking/order-picking-robot.html [dostęp 15.04.2017].

Starship Technologies, https://www.starship.xyz/ [dostęp 18.04.2017].

Viastore, http://www.us.viastore.com/warehouse-systems/robotics/ [dostęp 16.04.2017]. 